\title{
Optimaal gebruik van paardenmest
}

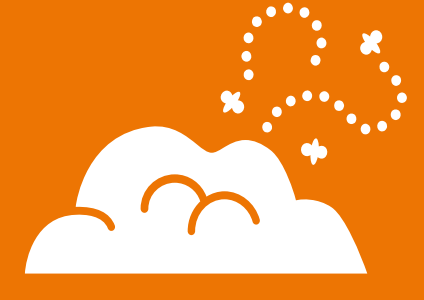




\section{Samenvatting}

De Paardenkamp (rusthuis voor oude paarden en pony's) wil bijdragen aan circulariteit en verkent de mogelijkheden voor het bewerken van stromest van het eigen bedrijf voor aanwending op bedrijfseigen percelen.

Nu wordt de stromest nog afgevoerd voor de champignonteelt en wordt runderdrijfmest aangewend op het land. Naast het aanwenden van verse stromest, wordt bekeken of compostering, fermentatie, mestvergisting of champost geschikte alternatieven zijn. De eindproducten verschillen in fysische en chemische eigenschappen,

\section{Summary}

The Paardenkamp Foundation (a rest home for retired horses) wishes to contribute to circularity and is exploring the possibilities to process and apply horse manure with straw on the own farm. Until now, solid horse manure is exported from the farm to be used elsewhere as mushroom substrate and liquid dairy manure from a nearby dairy farm is used for fertilization of the land. The following alternatives are studied: using horse manure for fertilization, composting of horse manure, fermentation and anaerobic digestion of horse manure. The end products differ in physical and evenals de aanwendingsmethoden voor vaste mest en drijfmest, nutriënten samenstelling en de emissies tijdens verwerking en aanwending op het land.

Ook de overlevingskansen van pathogenen en parasieten als wormen en de afbraak van medicijnresten verschilt tussen de verschillende processen.

Het advies is om de huidige werkwijze van mestafvoer te continueren. Vanuit oogpunt van circulariteit, bodem-

vruchtbaarheid, diergezondheid en bedrijfseconomie lijkt dit het beste compromis voor de Paardenkamp.
Samenvatting / Summary

Achtergrond en doelstelling

Onderzoeksactiviteiten

Colofon

chemical characteristics, e.g. application methods for solid and liquid manure products, nutrient levels in the products and gaseous emissions from processing and land application. Also the survival rates of pathogens such as parasites and worms and degradation rates of veterinary medicines may vary between the different technologies. It is concluded that adherence to the current working method (the replacement of horse manure with dairy manure for fertilization of the land) is the best compromise between circularity, soil fertility, animal health and economy of De Paardenkamp. 


\section{Achtergrond en doelstelling}

\section{De Paardenkamp}

De Paardenkamp, nationaal rusthuis voor oude paarden en pony's (www.paardenkamp.nl), is een idealistische instelling zonder winstoogmerk en bestaat dankzij giften. De stichting heeft de ANBI-status en geeft sinds 1962 aan oudere paarden een goed verzorgde 'oude dag'. Met inkomsten uit bijvoorbeeld legaten, testamenten en nalatenschappen kunnen uitbreidingen van

De Paardenkamp en haar opvanglocaties worden bekostigd. Sinds de jaren tachtig krijgt De Paardenkamp zóveel plaatsingsverzoeken dat er een lange wachtlijst is ontstaan. De mogelijkheid tot uitbreiding met de Birkhoeve in 2004 is dan ook met beide handen aangegrepen. In De Birkhoeve konden nog eens 60 paarden worden ondergebracht, zodat er totaal 120 paarden gehuisvest worden.

Behalve de functie van rusthuis, is de stichting ook kenniscentrum voor eigenaren/verzorgers van alle 45.000 bejaarde paarden in Nederland.

De Paardenkamp wil bijdragen aan de circulariteit en zoekt daarvoor mogelijkheden. Het item 'duurzaamheid' staat vermeld in de statuten en 'zelfvoorziening' is een speerpunt. In het verleden heeft Wageningen University \& Research onderzoeksvragen van de stichting voor een verantwoorde en duurzame manier van onkruidbestrijding beantwoord. Op basis van de succesvolle samenwerking is voor de huidige onderzoeksvraag wederom contact gelegd met Wageningen University \& Research.

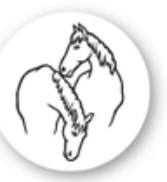

Stichting De Paardenkamp

\section{Wetenschapswinkel}

Wageningen University \& Research (WUR) ondersteunt via de Wetenschapswinkel onderzoeksprojecten op initiatief van maatschappelijke organisaties en van ondernemende (groepen) burgers. Met de Wetenschapswinkel geeft WUR invulling aan haar maatschappelijke taak.

\section{Aanleiding}

De Paardenkamp heeft een boerderijperceel (voorheen melkveehouderij) aangekocht om meer uitloopmogelijkheid te bieden aan de huidige populatie paarden.

De stichting bevindt zich in het voorstadium van planontwikkeling voor deze locatie. Dit gebeurt in overleg met de gemeente Soest en met advies van o.a. rentmeester Noordanus en een adviseur van Exlan.

Deze aangekochte locatie lijkt geschikt om de eigen paardenmest, na bewerking, aan te wenden op het eigen land om daarmee meer circulair te zijn.

\section{Doel}

Met dit onderzoek wordt duidelijk of en op welke wijze het mogelijk is om de mest van de nu aanwezige 120 paarden te bewerken en te hergebruiken op het eigen land. Doel is om hiermee zoveel mogelijk zelfvoorzienend te zijn als het gaat om mest en mineralen. Is het zinvol op de nieuwe locatie een opslag en verwerkingsinstallatie te bouwen en kan dit? Welke mogelijkheden zijn er, wat zijn de voor- en nadelen van verschillende opties en hoe ziet de kosten/ baten analyse er uit?

Het onderzoek draagt bij aan kennis rondom het verwerken en aanwenden van paardenmest op het eigen bedrijf of land in de omgeving van paardenhouderijen. Naast de huidige mogelijkheid om mest af te voeren naar champignonbedrijven kunnen paardenhouderijen wellicht gebruik maken van alternatieven. 


\section{Onderzoeksactiviteiten}

De activiteiten in deze studie richten zich op de verkenning van mogelijkheden voor het bewerken van paardenmest met stro van het eigen bedrijf voor aanwending op land van het eigen bedrijf. Zijn deze mogelijkheden toepasbaar op de nieuwe locatie van de Paardenkamp? En welke aspecten komen er daarbij om de hoek kijken?

Gezocht wordt naar antwoorden op de volgende specifieke vragen:

- Wat is samenstelling van de geproduceerde paardenmest?

- Wat is de mineralenbehoefte voor de grasproductie?

- Hoe zit het met emissies en stikstof $(\mathrm{N})$ verliezen bij opslag en aanwending?

- Aan welke eisen moet de bewerkte mest voldoen om bij te dragen aan een goede bodemkwaliteit?

- Is bewerking nodig?

- Welke rol spelen eventuele medicijnresten in de paardenmest bij bewerking en aanwending?

- Welke technieken zijn geschikt om strorijke paardenmest te verwerken voor aanwending op eigen land?

- Welke technieken zijn mogelijk op de locatie van de Paardenkamp?

- Zijn er technieken die wel op andere locaties zouden kunnen?

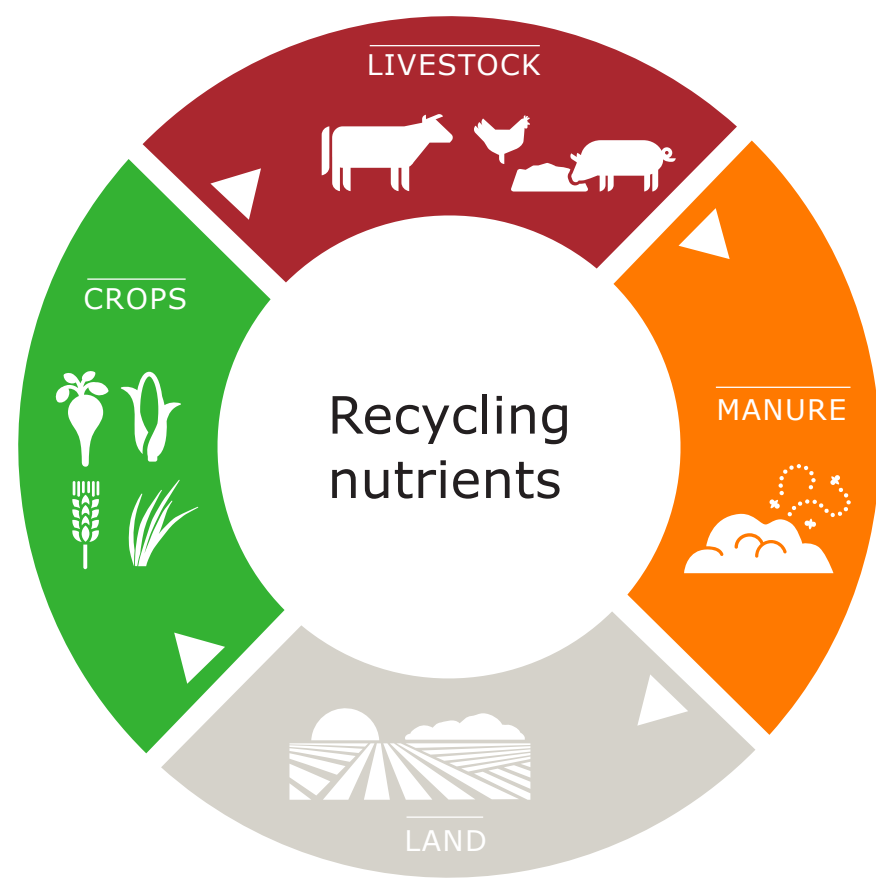

Circulariteit: "Het creëren van een bedrijf met een zo veel mogelijk gesloten kringloop door mest te recyclen en de bodemkwaliteit en biodiversiteit te stimuleren"

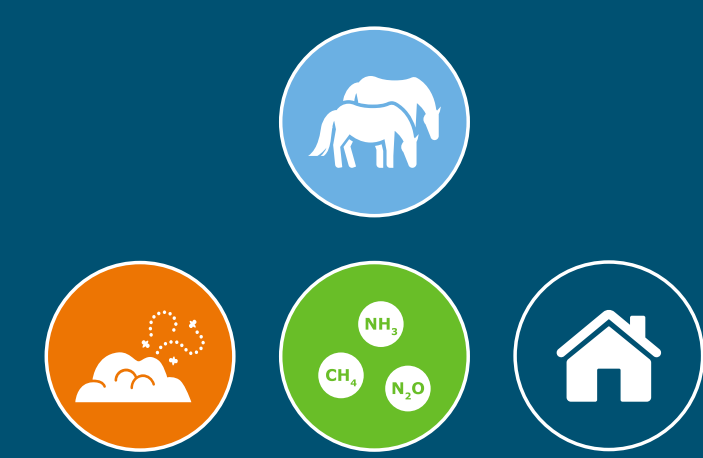




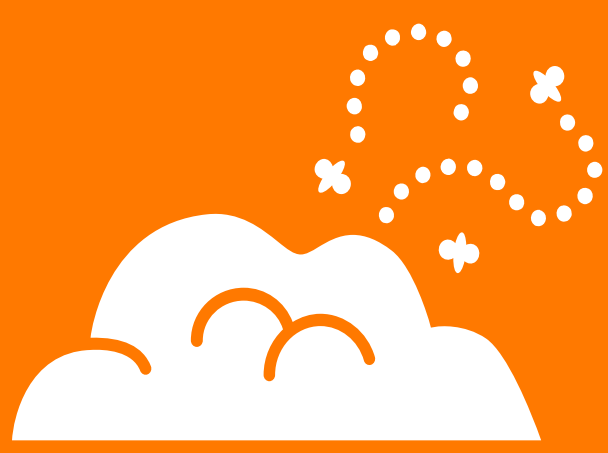

Verse strorijke paardenmest

\section{Eigenschappen}

- Alleen uitrijden tussen februari en september

- Veel organische N \& weinig minerale N

- Langzaam beschikbare N

- Veel (jonge) organische stof, voedt het bodemleven

- Verhoogt gehalte organische stof, waterhoudend vermogen \& N-leveringscapaciteit van de bodem (na 5-10 jaar)

- Te combineren met teelt van vlinderbloemigen $\rightarrow$ meng met hooi en kuilvoer

\section{Problemen}

- Opslag vereist gedurende het hele jaar

- Geuroverlast

- Kan ongedierte aantrekken

- Methaan en ammoniak emissies uit opslag en na aanwending

- Restanten van geneesmiddelen kan het bodemleven aantasten

- Vergroot het risico op verspreiding van parasieten via opname door het paard
Bruikbare technieken

\section{Verse mest}

2 Compostering

3 Fermentatie

4 Mestvergisting

5 Champost
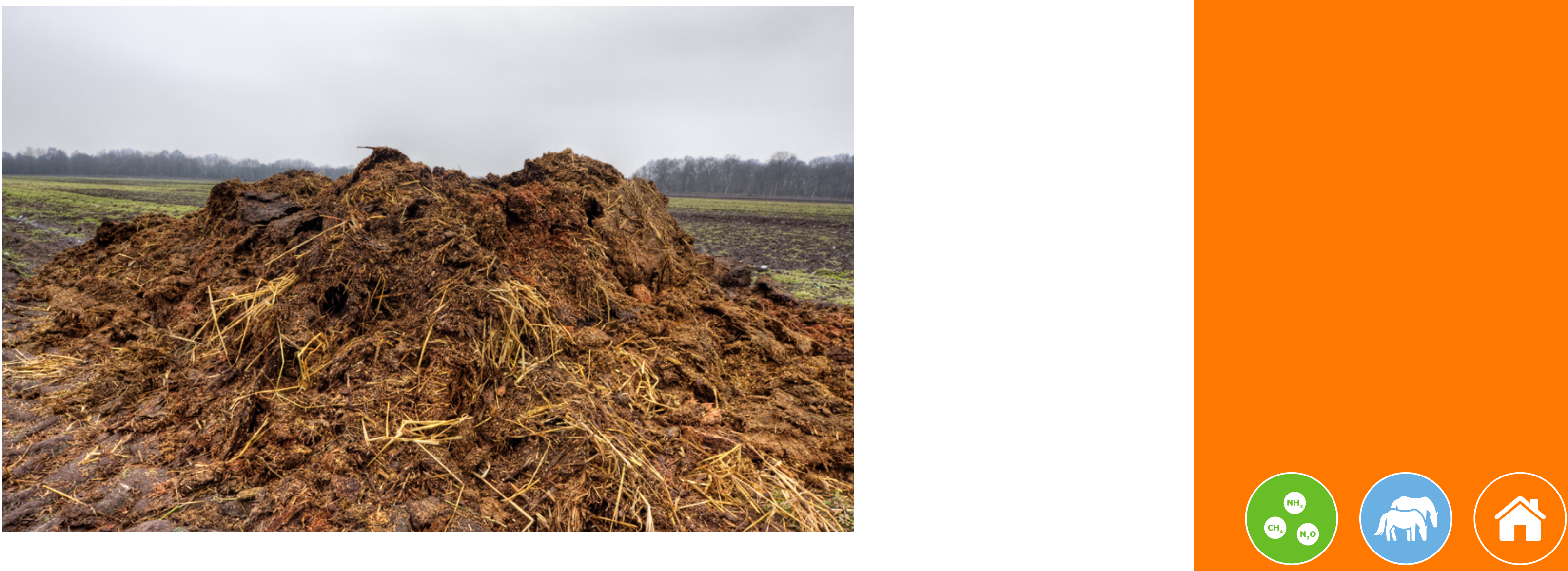


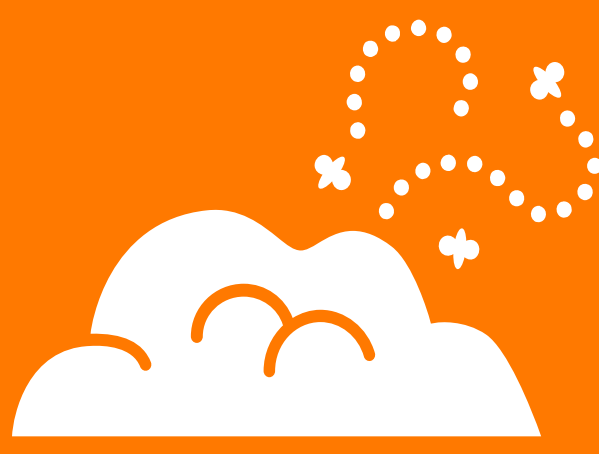

\section{Compostering}

\section{Eigenschappen}

- Natuurlijk proces van omzetting van organisch materiaal door zuurstof minnende (aerobe) bacteriën

- Bodemverbeteraar, traag werkende meststof met langdurige werking

- Materiaal slinkt 30-50\% tijdens proces $\rightarrow$ afname massa/volume, makkelijker in gebruik

- $\mathrm{N}$-verlies ca. $30 \%$ bij vakkundige compostering (anders hoger)

- Doden van de meeste pathogenen, pathogene eitjes en onkruidzaden (temperatuur rond de $65^{\circ} \mathrm{C}$ )

\section{Proces}
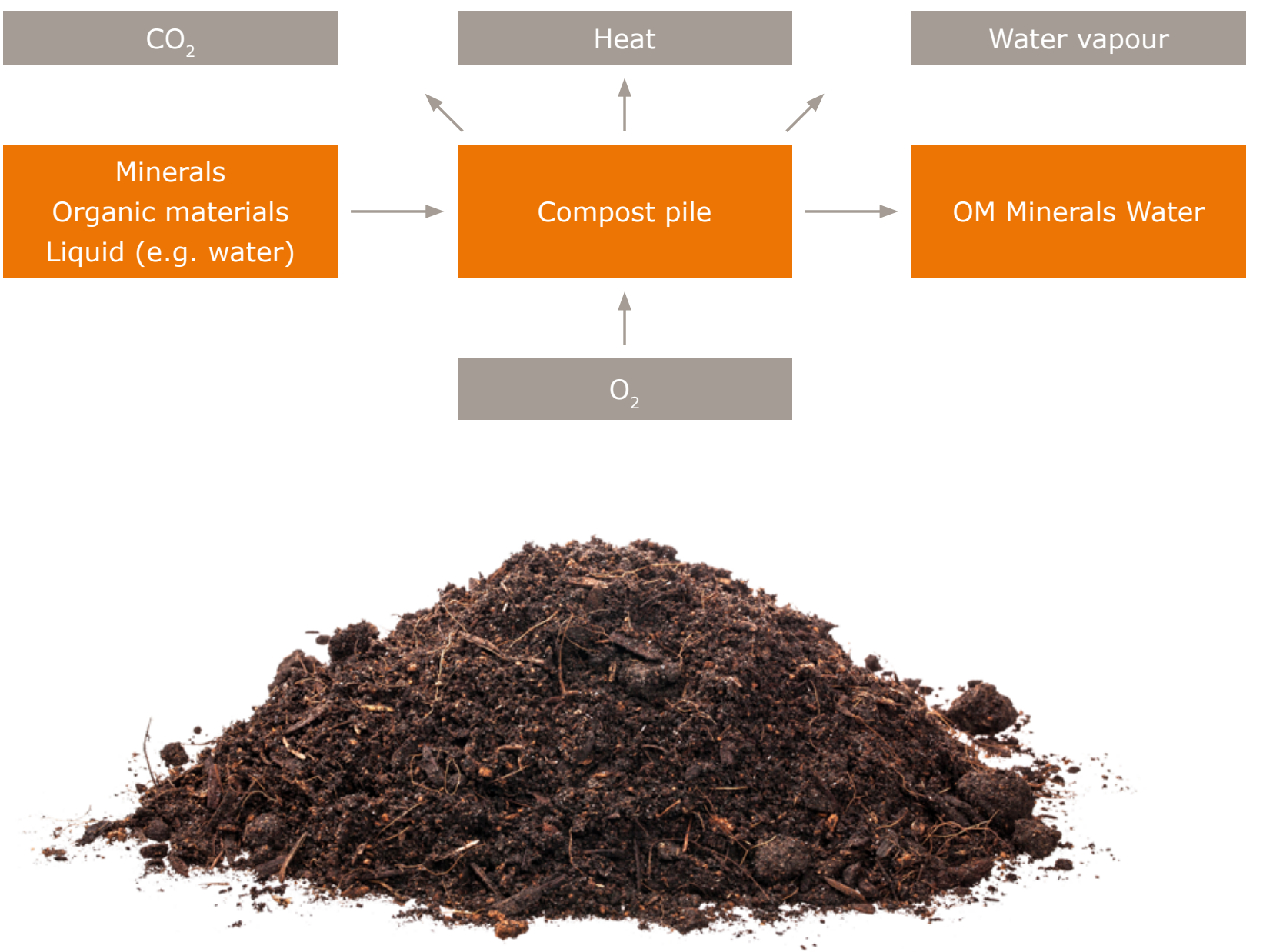

Bruikbare technieken

1 Verse mest

\begin{tabular}{l}
\hline 2 Compostering \\
\hline 3 Fermentatie \\
\hline 4 Mestvergisting \\
\hline 5 Champost \\
\hline
\end{tabular}

5 Champost

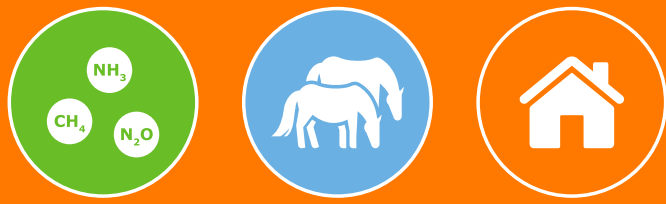




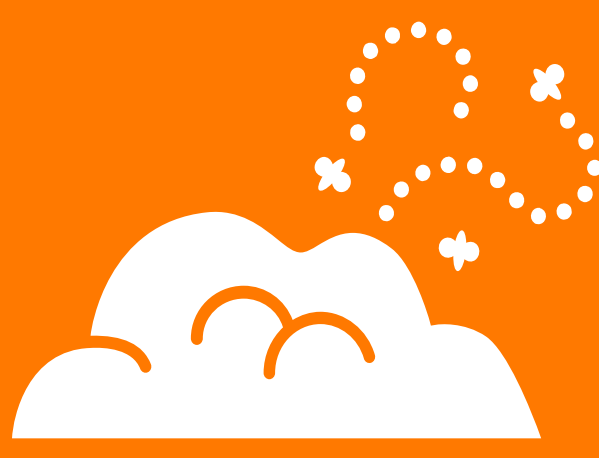

\section{Vormen van compostering}

\section{Buiten composteren}

- Vocht, temperatuur en zuurstofconcentraties $\rightarrow$ niet volledig gecontroleerd

- Veel verlies van $\mathrm{N}$ tijdens proces door vervluchtiging; dit is afhankelijk van het seizoen en kan $33-45 \%$ bedragen

- Gecomposteerde mest is stabiel

\section{Windrow composteren}

- Toevoer zuurstof door omscheppen

- Veel arbeid

\section{Tunnel composteren}

- Toevoer zuurstof met buizen

- Minder arbeid

- $\mathrm{NH}_{3}$ gevangen door luchtwasser

\section{Binnen composteren}

- Controleren van omgevingsfactoren

(zuurstof, vochtigheid e.d.)

- Constante aanvoer van zuurstof

- Hogere kwaliteit eindproduct

- Mogelijkheid om vervluchtigde $\mathrm{N}$ te vangen met een luchtwasser en spuiwater te gebruiken als kunstmestvervanger

- Hoog in kosten, veel mest nodig (groter bedrijf)

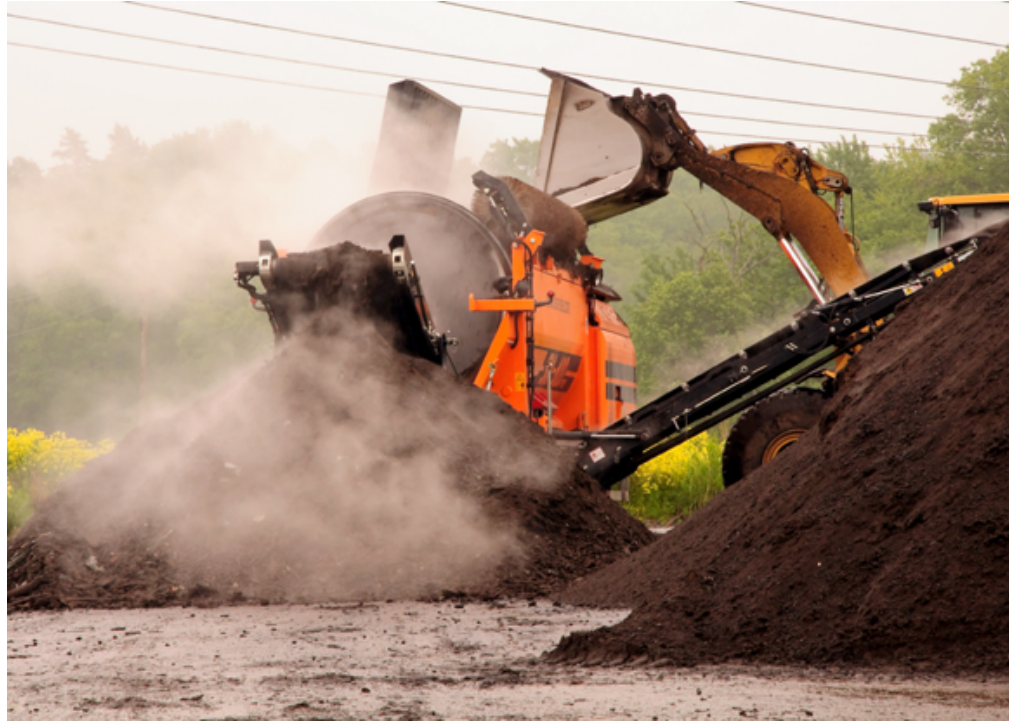

\begin{tabular}{l} 
Bruikbare technieken \\
1 Verse mest \\
\hline 2 Compostering \\
\hline 3 Fermentatie \\
\hline 4 Mestvergisting \\
\hline 5 Champost \\
\hline
\end{tabular}
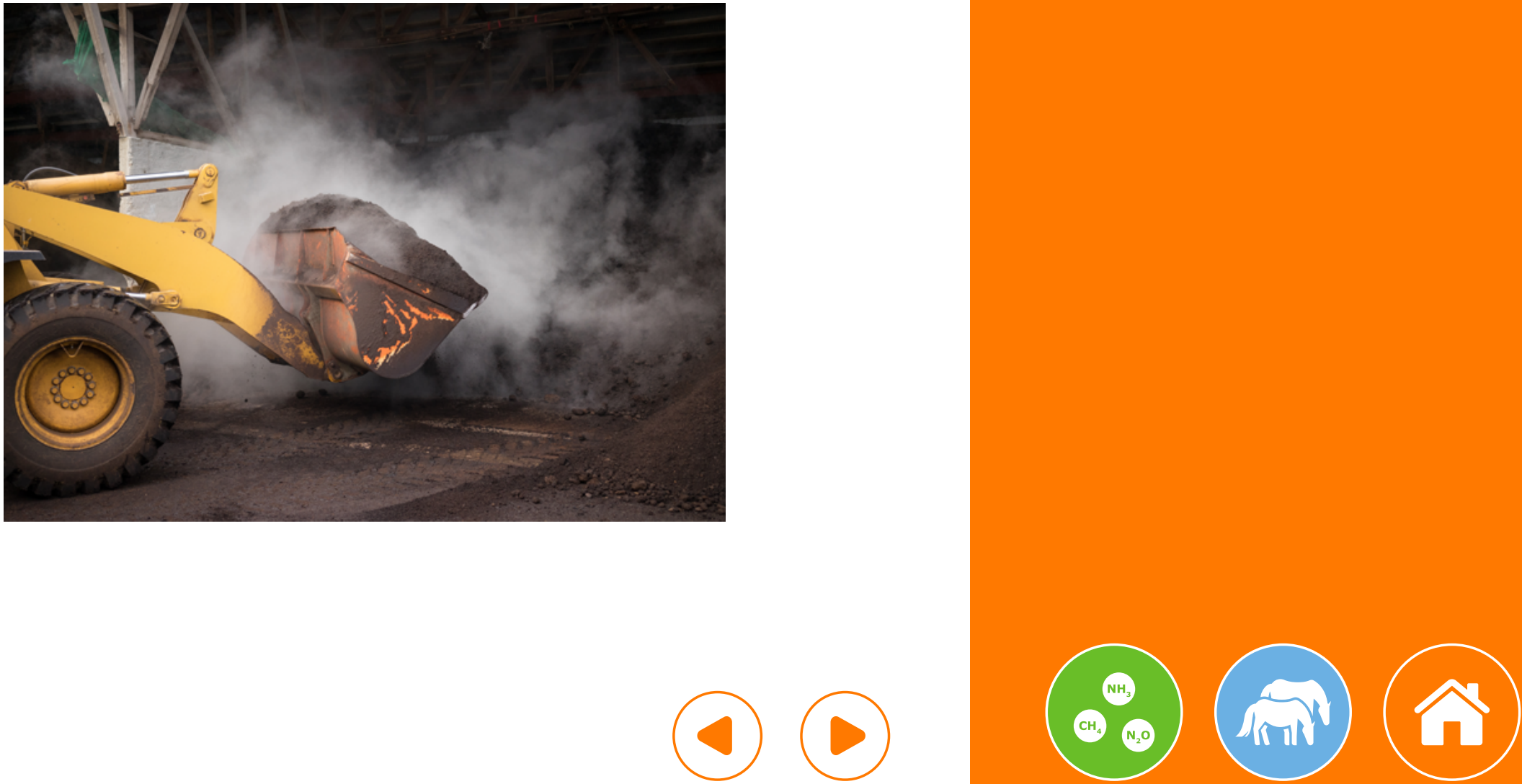


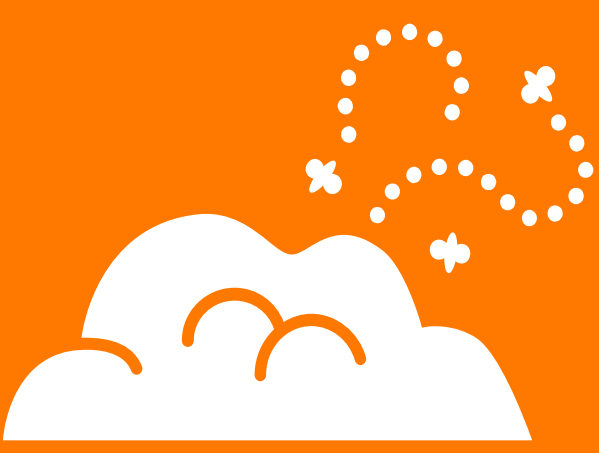

Eindproduct

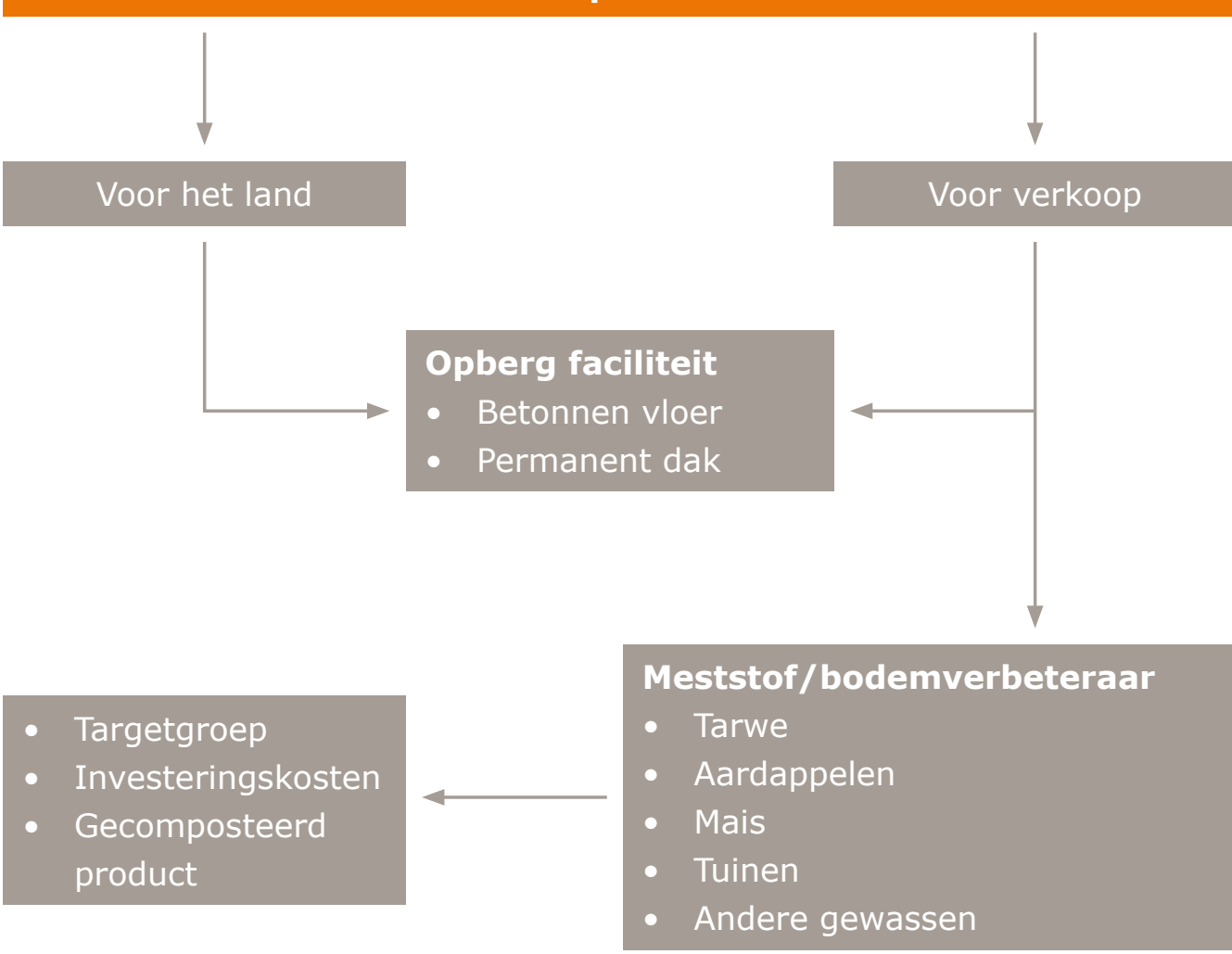

Bruikbare technieken

1 Verse mest

\section{Compostering}

3 Fermentatie

4 Mestvergisting

5 Champost

- Andere gewassen 


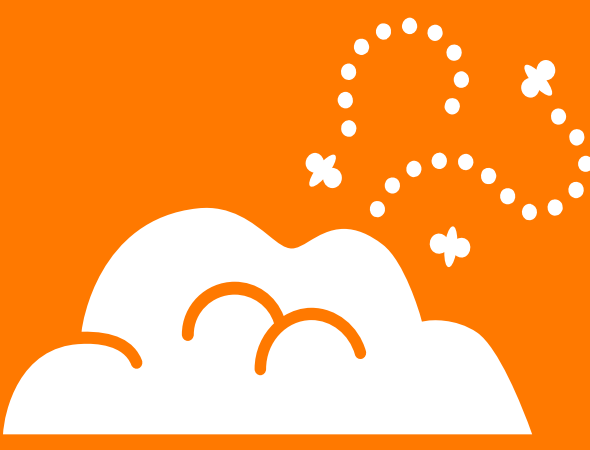

\section{Fermentatie}

- Biologisch proces van omzetting afbraak van organisch materiaal door micro-organismen bij laag zuurstofgehalte onder lage zuurstof condities

- Twee methoden

- Besproeien van vaste mest met anaerobe bacteriën en afdekken met plastic (inkuilen)

- De groeiende mestlaag in de stal wekelijks

besproeien met melkzuurbacteriën.

- Temperatuur $30-40^{\circ} \mathrm{C}$ (te laag voor inactiveren van micro-organismen)

- Na 2-6 maanden geschikt als meststof

\section{+ punt}

- Stikstof en organische stof in het gefermenteerde eindproduct en beperkte $\mathrm{NH}_{3}$ emissie

- Verlies organisch materiaal $10-20 \%$, stikstof $(\mathrm{N})$ $5-10 \%$

- Op lange termijn meer beschikbare nutriënten voor gras

- punt

- Geen hygiënisatie, dus geen doding parasieten en wormen

- Kans op vervluchtiging bij aanwending

- Beperkte beschikbaarheid onderzoeksresultaten over effect van fermentatie

- Volgens wetgeving geen meststof

Bruikbare technieken

1 Verse mest

2 Compostering

3 Fermentatie

4 Mestvergisting

5 Champost 


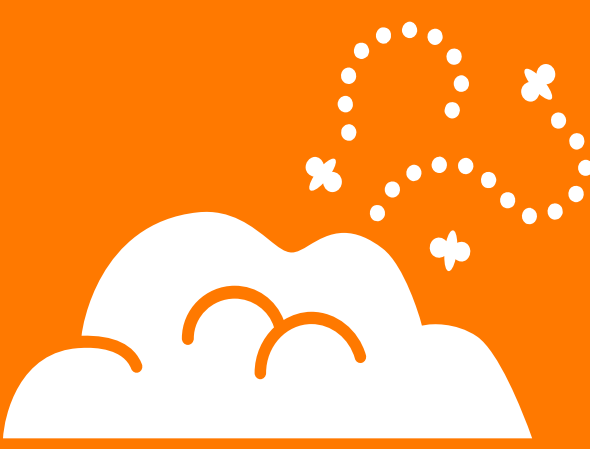

\section{Mestvergisting - biogas}

- Combinatie van processen voor de afbraak van organische materialen door anaerobe microorganismen

- Producten zijn biogas en digestaat

- Biogas is een mix van hoofdzakelijk methaan $\left(\mathrm{CH}_{4}\right)$ en koolstofdioxide $\left(\mathrm{CO}_{2}\right)$

- Biogas is een bron van hernieuwbare energie

- Digestaat is rijk aan nutriënten en kan dienen als meststof en bodemverbeteraar

- Het is niet gebruikelijk paardenmest te vergisten; vaste mest kan niet verpompt worden. Mengen met drijfmest is dan een optie, maar het stro kan een blokkade vormen. Eventueel mest aanlengen met water en stro versnijden.
- De $\mathrm{C}: \mathrm{N}$ verhouding van paardenmest met stro valt binnen de optimale range voor vergisting.

- Paardenmest heeft door de hoge $\mathrm{C}: \mathrm{N}$ verhouding een hogere potentie voor energielevering dan andere mestsoorten
Bruikbare technieken

1 Verse mest

2 Compostering

3 Fermentatie

4 Mestvergisting

5 Champost
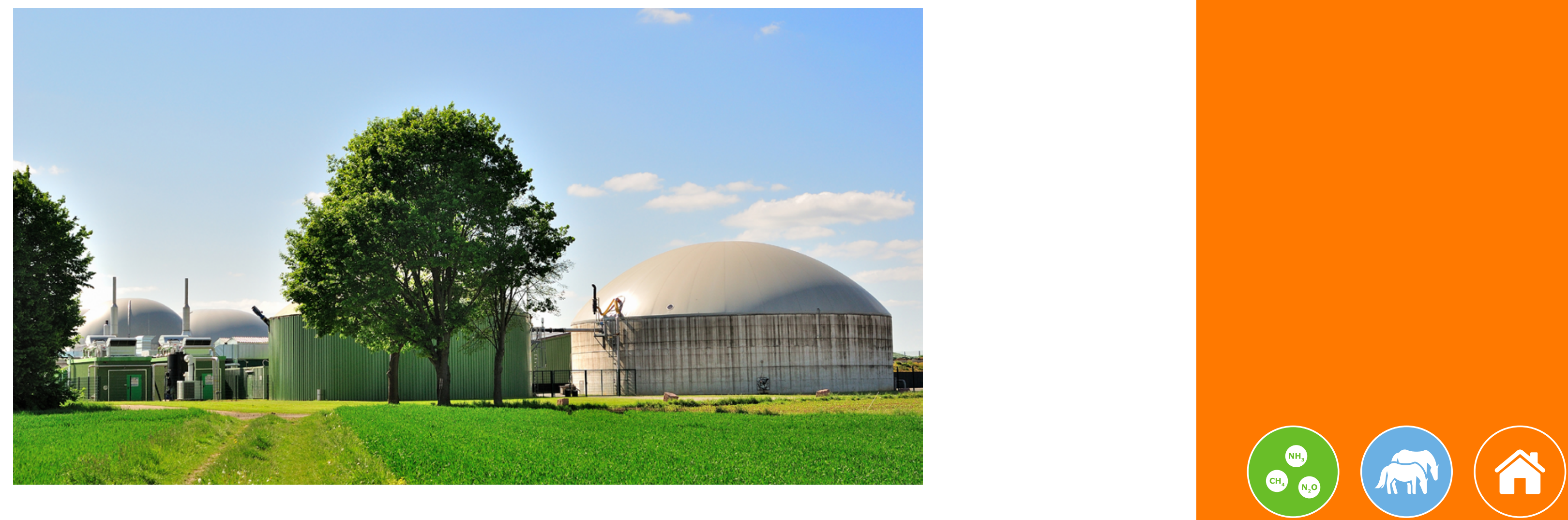


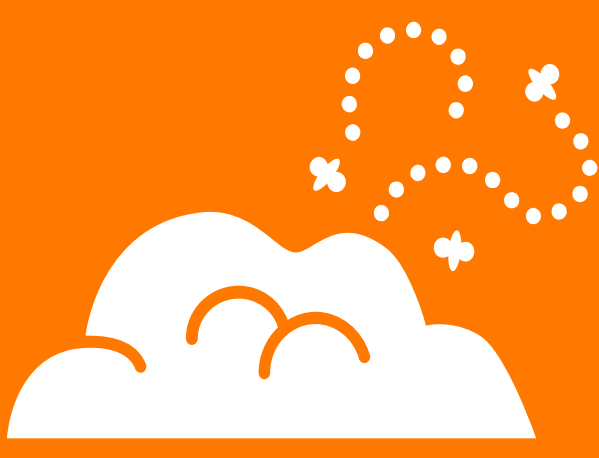

\section{Champost}

- Paardenmest wordt hierbij van het bedrijf afgevoerd en ingezet als substraat bij championteelt

- Hierbij wordt paardenmest gemengd met andere materialen

- Bestaat uit $20 \%$ dekgrond en een nutriëntenrijke substantie van tarwestro, gips/krijt, vleeskuikenmest en paardenmest
- Champost is restproduct na champignonteelt

- Varieert sterk in vochtgehalte

- Champost wordt gezien als dierlijke mest

- $\mathrm{N}$ benutting is $25 \%$ (rundveemest $60 \%$ ) in het eerste jaar na toediening (ook nog nawerking)

- Hoog zoutgehalte kan nadelig zijn voor grond en gewassen

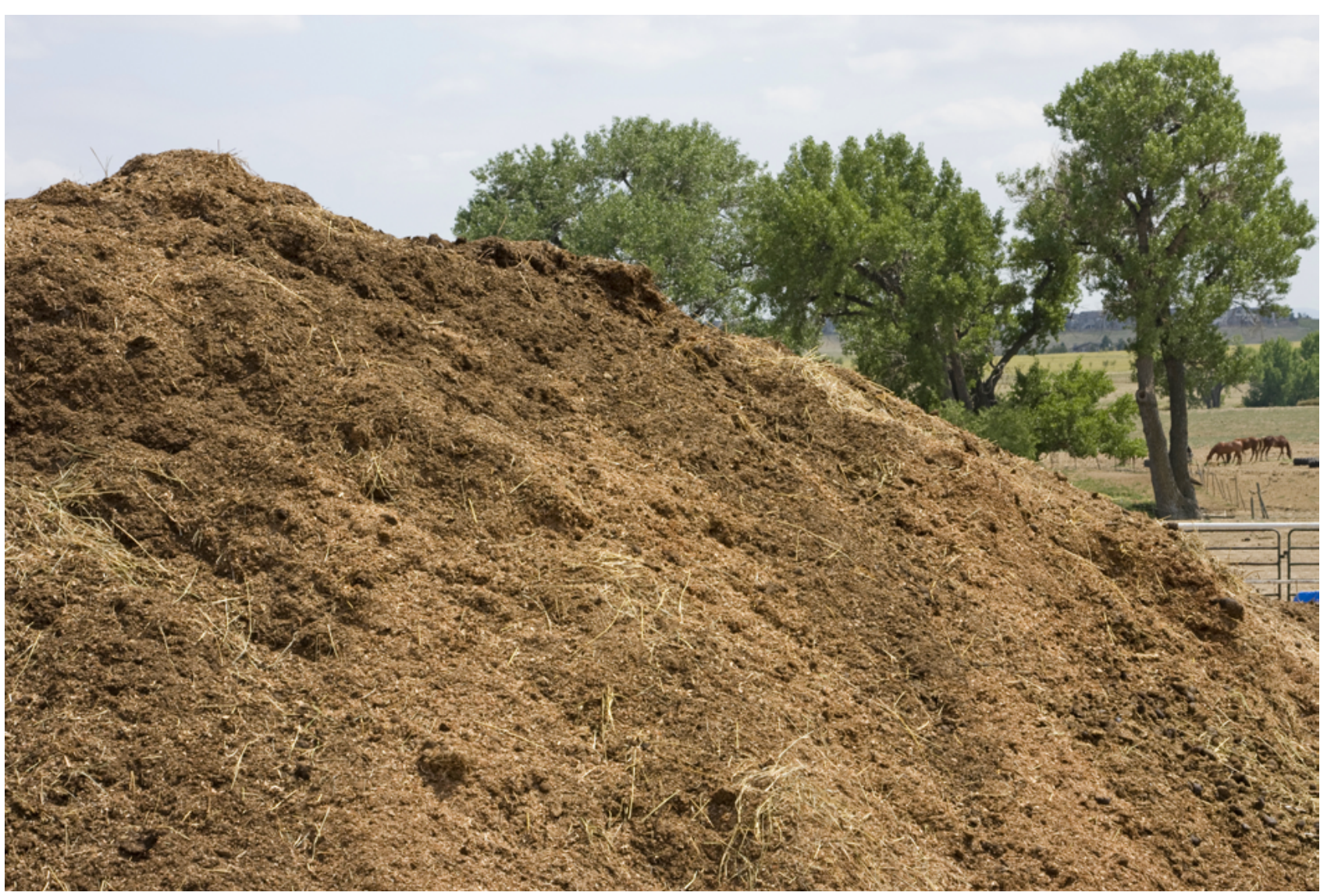

\begin{tabular}{l} 
Bruikbare technieken \\
1 Verse mest \\
\hline 2 Compostering \\
\hline 3 Fermentatie \\
\hline 4 Mestvergisting \\
\hline 5 Champost
\end{tabular}

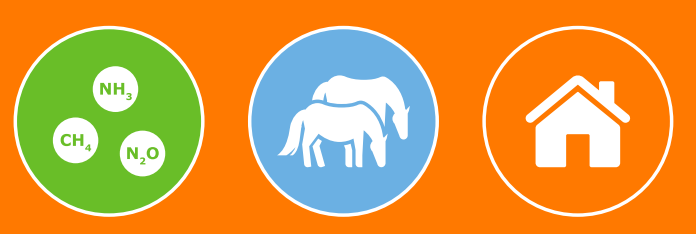




\section{Emissies en stikstofverliezen}

Drie belangrijkste gassen die uit paardenmest emitteren: Ammoniak $\left(\mathbf{N H}_{3}\right)$, Methaan $\left(\mathbf{C H}_{\mathbf{4}}\right)$ en Lachgas $\left(\mathbf{N}_{\mathbf{2}} \mathbf{O}\right)$. Methaan en stikstofoxide zijn broeikasgassen, terwijl ammoniak tot verzuring van de omgeving kan leiden.

\section{Verse paardenmest}

veel methaan- en $\mathrm{CO}_{2}$-emissie uit

stal en tijdens opslag, er kan ook

vrij veel $\mathrm{NH}_{3}$ emitteren en daarnaast

wat $\mathrm{N}_{2} \mathrm{O}$. $\mathrm{Na}$ aanwending is er nog

wat $\mathrm{NH}_{3}$-emissie.

\section{Compostering}

veel $\mathrm{CO}_{2}$-emissie tijdens proces,

ook wel methaanemissie, en daar-

naast emissie van $\mathrm{NH}_{3}, \mathrm{~N}_{2} \mathrm{O}$ en $\mathrm{N}_{2}$.

Uit het eindproduct lage emissies

na aanwending.

\section{Vergisting}

veel methaan- en $\mathrm{CO}_{2}$-emissie

tijdens het proces (beetje $\mathrm{NH}_{3}$ ), daarna ook nog methaan- en $\mathrm{CO}_{2}-$ emissie tijdens opslag en emissie van $\mathrm{NH}_{3}$; na aanwending vooral emissie van $\mathrm{NH}_{3}$ en enige $\mathrm{N}_{2} \mathrm{O}$.

Onbehandelde paardenmest leidt tot ammoniak- en methaanemissies tijdens opslag, composteren leidt vooral tot ammoniak- en lachgasemissies tijdens het composteerproces en vergisten geeft vooral hogere ammoniak- en lachgasemissies bij aanwending van het digestaat.

\begin{tabular}{llll} 
Wat emitteert? & Onbehandelde mest & Gecomposteerde mest & Vergiste mest \\
\hline Uit opslag & Methaan & Ammoniak & Stikstofoxide \\
& Methaan & \\
\hline
\end{tabular}

Tijdens aanwending

Ammoniak

Vrijwel geen uitspoeling bij gecomposteerde mest, beetje bij drijfmest en wat meer bij kunstmest.

Vervluchtiging stikstof hoogste bij runderdrijfmest, gevolgd door kunstmest en dan gecomposteerde mest.

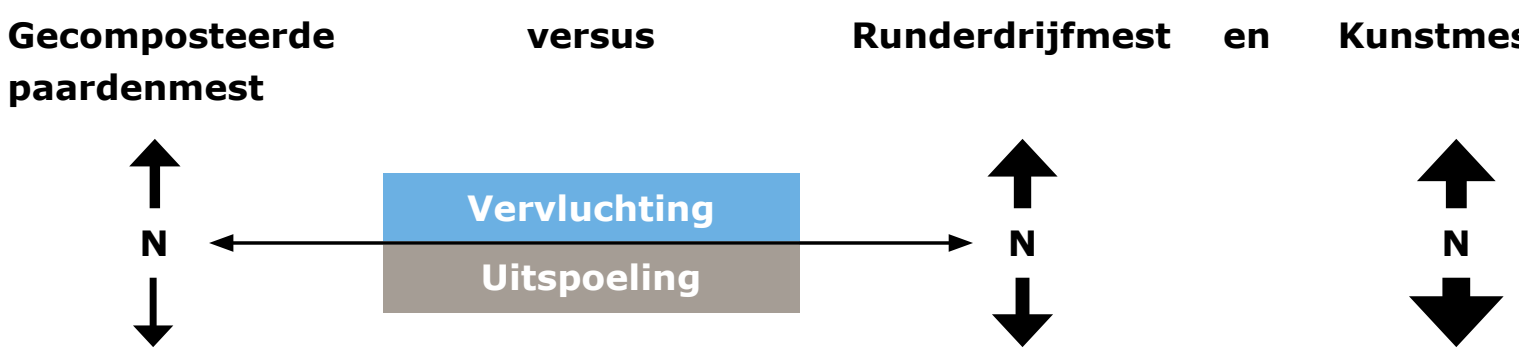




\section{Bemestingswaarde}

Verse mest bevat veel organisch materiaal en organische stikstof, terwijl minerale stikstof vervluchtigt bij aanwending. De gemiddelde $\mathrm{N}$-efficiëntie van minerale stikstof is $30-35 \%$ op grasland, maar hoger op bouwland.

Tijdens compostering vervluchtigt $\mathrm{NH}_{4}+$, zodat gestabiliseerde compost alleen $\mathrm{N}$ in organische vorm bevat. Dit beperkt de bemestingswaarde voor grasland.
Digestaat dat vrijkomt bij vergisting bevat een iets hoger gehalte aan minerale stikstof, maar minder organische stikstof dan verse mest.

Bij aanwending van verse mest en compost op grasland moet de Paardenkamp nog steeds (minerale) mest aankopen, door het tekort aan minerale stikstof.

De Paardenkamp heeft namelijk gras met een hoog eiwitgehalte nodig.

Samenstelling mest Paardenkamp

totaal-N totaal-P totaal-K

$\mathbf{g} / \mathbf{k g}$

$\mathbf{g} / \mathbf{k g}$

$\mathbf{g} / \mathbf{k g}$

ammonium-N

droge stof

$\mathbf{g} / \mathbf{k g}$

$\mathbf{g} / \mathbf{k g}$

as

$\mathbf{g} / \mathbf{k g}$

8,49

1,69

11,99

1,79

319,6

78,7

132

$\mathrm{NO}_{3} \mathrm{IC}$

g/ kg

- Mest van Paardenkamp heeft hoge gehaltes aan $\mathrm{N}$ en $\mathrm{P}$.

- Aandeel minerale $\mathrm{N}$ is met $21 \%$ hoog, wat gunstig is (normaal circa is $11 \%$ ).

- $\mathrm{C}$-gehalte is hoog; door hoge $\mathrm{N}$-gehalte is $\mathrm{C} / \mathrm{N}$ verhouding met 15,5 gemiddeld. 
- De Paardenkamp gebruikt verschillende anthelmintica om de paarden te ontwormen

- Werkzame middelen zijn ivermectine, moxidectine, fenbendazole en praziquantel

\section{Verse paardenmest}

- Zonder enige vorm van mestverwerking, hebben medicijn

residuen een negatief effect op de biodiversiteit van de bodem.

\section{Compostering}

- Reduceert de concentratie van ivermectine in mest

- Ivermectine heeft geen negatief effect op het composteringsproces

- Het eindproduct kan zonder negatieve effecten voor paarden of nuttige insecten aangewend worden.

\section{Vergisting}

- Aanwezige medicijnen kunnen een remmend effect hebben op het vergistingsproces

- Voor afbraak van medicijnen is waarschijnlijk een hogere temperatuur nodig.

\section{$\mathrm{CH}_{4}$}

Aspecten bewerking

\& aanwending

1 Emissies en stikstof verliezen

2 Bemestingswaarde

3 Medicijn residuen

en parasieten 


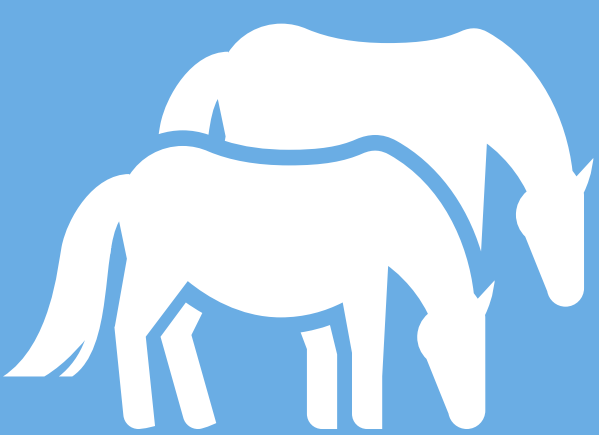

\section{Rangschikking advies}

Voor de situatie op de Paardenkamp, worden 4 opties voorzien, die hieronder in volgorde van aanbeveling gerangschikt staan. Daarnaast wordt een alternatief bekeken.

\section{Mest blijven afvoeren}

Positief: huidige situatie

$\mathrm{N}$ verliezen, grassamen-

stelling, kosten, arbeid,

medicijnresten \& parasi-

taire besmetting.

\section{Circulair:}

- Deel van de

paardenmest wordt

nu ter verbetering van

bepaalde percelen

gebruikt

- Op gedeelte van de percelen vindt maïsteelt

plaats, waarvoor

runderdrijfmest wordt

uitgeruild.

\section{Binnen composteren}

- Investeringen \& arbeid

- Genereert hoge

kwaliteit compost gemakkelijk

gereguleerd \& gebruik van spuiwater

\section{Anaerobe vergisting}

- Investeringen, arbeid \& expertise

- Co-vergisting, digestaat kan gebruikt worden als meststof \& genereert groene energie

\section{Buiten composteren}

- Lage kosten 8 arbeidsvereisten

- Aanzienlijke verliezen voor het milieu 


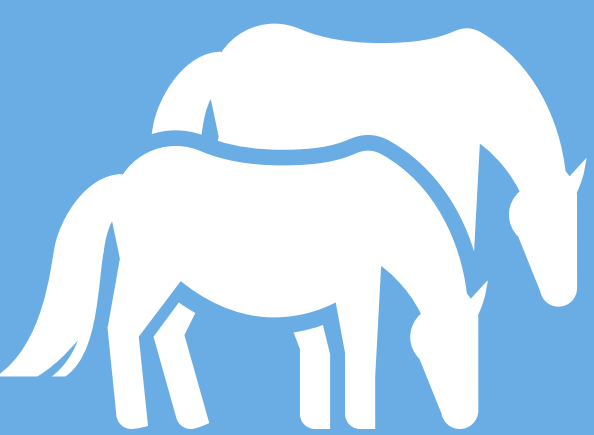

\section{Teelt van luzerne}

Luzerne is van nature zeer rijk aan eiwit, (ca $16 \%$ ruw eiwit). Luzerne wordt ook vaak gevoerd aan oude paarden, omdat de korte stengels gemakkelijk worden gekauwd, ook met een verminderd gebit, en deze voedzame aanvulling de senioren op gewicht kan

houden. Luzerne is van nature arm aan suikers. Luzerne bevat gemiddeld 3,3\% suiker, terwijl grashooi gemiddeld $10 \%$ suiker bevat. Daarom is luzerne ook zeer geschikt voor paarden die gevoelig zijn voor suiker, zoals bij insulineresistentie, EMS en hoefbevangenheid.

\section{Nadeel}

Luzerne moet voor de paarden erg fijn gemaakt worden anders worden de "harde" stengels slecht gegeten door de paarden (ervaring van de Paardenkamp).

\section{Potentie}

Paardenhouders zouden kunnen kijken of omliggende agrariërs met kennis van de teelt bereid zijn om luzerne te telen. Als dit gehakseld wordt, kan het onderdeel van het rantsoen gemaakt worden. Luzerne kan goed afgewisseld worden met maïsland en grasland en kan in het rantsoen als vezelbron dienen door het met krachtvoer te mengen, hetgeen de circulariteit bevordert.

www.voervergelijk.nl/fabels-en-feiten/20/feiten-enfabels-over-luzerne

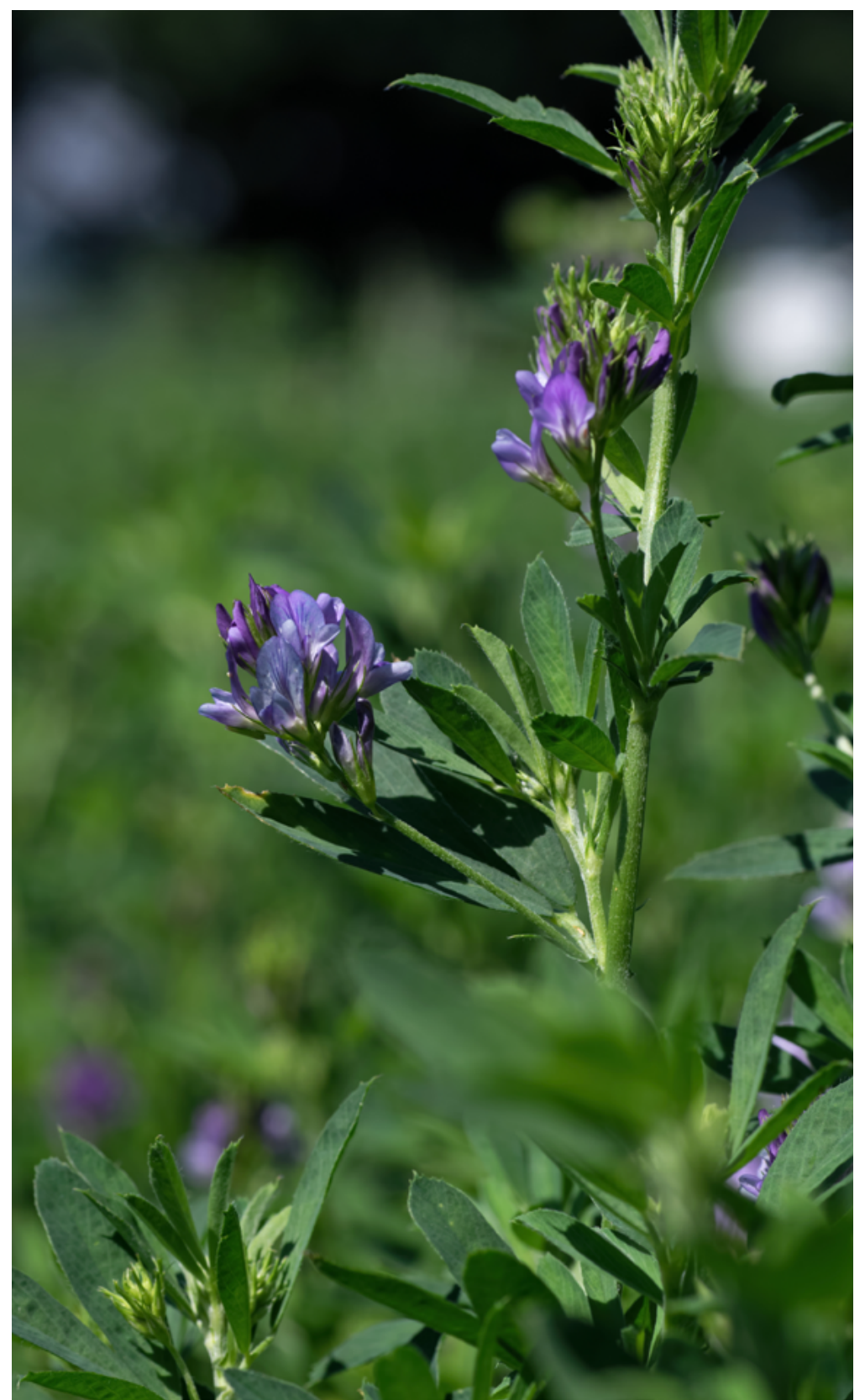

Rangschikking advies

1 Rangschikking advies

2 Teelt van luzerne

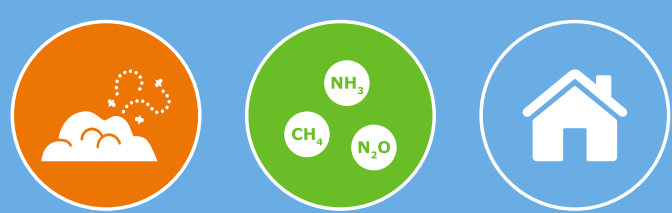




\section{Colofon}

Titel

Optimaal gebruik van paardenmest

Trefwoorden

Keywords

Opdrachtgever

Projectuitvoering

Projectcoördinatie

Financiële ondersteuning

Begeleidingscommissie

Fotoverantwoording

Vormgeving

Bronvermelding

DOI

ISBN

$10.18174 / 464226$

978-94-6343-539-0

Stromest, circulariteit, paarden

Solid manure, circularity, horses

Stichting De Paardenkamp

Izak Vermeij

Henk Ebbers (LTO Paardenhouderij)

Roland Melse (WLR)

IJsbrand Mulder (De Paardenkamp)

Izak Vermeij (WLR)
Samenvatting / Summary

Achtergrond en doelstelling

Onderzoeksactiviteiten

Colofon

Herman de Boer, Fridtjof de Buisonje, Roland Melse en Izak Vermeij

Studenten: Tijn van den Aker, Anne-Lotte Boudeling, Alice Hirons,

Sharita Kanhailal, Emanuele Ribatti, Jari van der Stok

Wageningen University \& Research, Wetenschapswinkel

Gepco van Bokhorst (De Paardenkamp)

Roy Floot (Agrifirm Exlan, Instituut voor Agrarisch Recht)

Lèneke Pfeiffer (Wetenschapswinkel)

De foto's en figuren zijn vervaardigd door de auteurs of de meewerkende studenten, tenzij anders aangegeven

Communication Services, Wageningen University \& Research

Verspreiding van het rapport en overname van gedeelten eruit worden aangemoedigd, mits voorzien van deugdelijke bronvermelding

Wageningen University \& Research, Wetenschapswinkel rapport 346

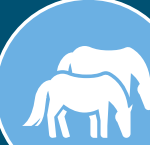

